DOI $10.51558 / 2490-3647.2021 .6 .3 .411$

UDK 373.3:37.018.2

Primljeno: 20. 05. 2021.

Izvorni naučni rad

Original scientific paper

\title{
Gabriel Pinkas
}

\section{PERCEPTION OF SCHOOL CLIMATE AS A MEDIATING FACTOR IN RELATION BETWEEN TEACHER MOTIVATION AND THE PERCEIVED SCHOOL PRINCIPAL LEADERSHIP STYLE}

\begin{abstract}
This paper presents the results obtained on a sample of 467 teachers from 25 elementary schools in the wider city area of Tuzla. The subject of the research was the relationship between the principal leadership styles, as perceived by teachers, and the work motivation of teachers, through the perception of the school climate as a potential determinant of this relationship. The Multifactor Leadership Questionnaire (MLQ), the Work Tasks Motivation Scale for Teachers (WTMST), and the School Level Environment Questionnaire (SLEQ) were used to collect data. The obtained results indicate that the principal leadership style, perceived by teachers, affects teacher motivation directly, and indirectly, through the teachers' perception of the school climate. This, however, explains a small part of the total variance of motivation, which suggests that motivation is mostly determined by the sum of other factors.
\end{abstract}

Keywords: teacher motivation; school climate; school principal; transformational, transactional, laissez-faire leadership; self-determination theory

\section{INTRODUCTION}

The first successful attempt to scientifically identify and describe leadership, which in practice probably occurred with the first social groups, dates to 1939 and American social psychologists K. Lewin, R. Lippit and R. K. White. They pointed to three fun- 
damental types of leader attitudes toward group members: autocratic, democratic, and laissez faire (Lewin, Lippit \& White 1939). Depending on the type of leader, the group's performance differs in terms of achieving common work goals (Krech, Crutchfield \& Ballachey 1969). All three authors conclude that, in the medium and long term, the best results are achieved by the democratic behaviour of the leaders. In the short term, autocracy is most effective, while laissez faire leadership in most cases leads to the lowest achievement.

Applying general knowledge of leadership to work organizations, Bass (1985) identifies transformational, transactional, and laissez faire leadership. The first contains elements of democratic and the second contains elements of autocratic leadership style. According to Bass and Riggi (2006), a particularly significant aspect of transformational leadership is that it leads to changes in employees themselves; it raises the level of motivation and shapes them morally.

The relationship between leadership style and employee motivation has also aroused the interest of researchers in the field of education. Eyal and Roth (2011) found a positive correlation between transformational leadership and intrinsic motivation, as well as between transactional leadership and extrinsic motivation. Wasserman, Ben-eli, Yehoshua and Gal (2016) reported multiple positive correlations of variables related to the perceived leadership style of the school principal, perception of profession, and teacher initiative in doing their job. Alasad (2017) points to a positive connection between the transformational leadership style and the intrinsic motivation of teachers, and even a somewhat stronger connection between this principal leadership style and extrinsic motivation. Shepherd-Jones and Salisbury-Glennon (2018) found a positive association between autonomy, commitment and competence in teachers' task performance and the democratic style of leadership used by school principals. Eres (2011) and Gilbar (2015), on the other hand, did not find a significant correlation between the perceived principal leadership style and teacher motivation.

Besides the relationship between leadership style and motivation, the relationship between the perceived principal leadership style and the perception of the climate also caught the attention of school climate researchers. Thus, DuPont (2009) found a positive relationship between the instructional style of school principal leadership and teacher cooperation, as dimensions of the school climate. Gumus, Bulut and Bellibas (2013) suggest the existence of a link between the principal's monitoring of the teaching process, giving feedback, and setting and expressing clear goals with teacher collaboration. In a study by Allen, Grigsby and Peters (2015) the idealized influence of school principals at the level of attribution and behaviour (dimensions of transfor- 
mational leadership) showed a predictor value for perceiving mutual teacher collaboration. Silva, Amante and Morgado (2017) reported on the positive connection between the principal leadership style and the cooperation of teachers in the fields of recreational and educational activities, activities related to curriculum development and activities of an interdisciplinary nature.

Some researchers (Ladyong 2014; Raman, Ling, \& Khalid 2015) have also addressed the relationship between school climate and teacher motivation, but there is no research in the available literature that takes into consideration the school principal leadership style, teacher work motivation and school climate at the same time, with the assumption that climate, asides from being related to leadership itself, also has a potentially mediating role between leadership and motivation. That is why the focus of this paper is researching the mediating role of the teachers' perception of the school climate in the relationship between the principal leadership style, as perceived by teachers, and the work motivation of teachers in primary schools.

In general, a higher level of motivation and dominant intrinsic motivation in teachers are important for pedagogical practice and theory because there is knowledge that these factors are correlated with teachers' commitment to work, and, ultimately, with student achievement and achievement of school educational goals (Gorozidis and Papaioannou 2014; Jesus and Lens 2005; Karabenick and Conley 2011; Perlman 2013). Understanding the matter of direct and indirect role of school principals' leadership style and school climate in creating teacher motivation could therefore improve teaching theory and practice.

\section{TRANSACTIONAL, TRANSFORMATIONAL AND LAISSEZ FAIRE LEADERSHIP}

The theoretical framework in this paper is comprised of the three leadership styles described by Bass (1985): transformational, transactional, and laissez faire leadership. Transformational leadership is, according to Avolio and Bass (2002), a type of leadership that leads to changes within individuals and social systems in terms of motivation, moral shaping and work performance. This is accomplished through the following mechanisms: creating a common identity between group members and in the group as a whole; the leader is a role model for personal identification for employees; the leader understands the needs, strengths and weaknesses of employees, according to which he gives them appropriate tasks. 
The dimensions of transformational leadership (Bass 1990) are: 1. individualized consideration (refers to the attention the leader pays to the employee and his understanding of the employee's needs), 2. intellectual stimulation (the degree to which the leader accepts employee ideas and encourages his creative thinking), 3. inspirational motivation (leader's ability to articulate goals and get the employees to achieve them), 4. idealized influence - attributed and behaviour (the degree to which the leader represents a moral ideal for the employee, gains his respect and trust).

Transactional leadership is based on the take-give principle. In this case, the leader gives employees guidance, recognition and a value system, and in return he takes/receives respect and obedience. It consists of: 1. contingent reward, 2. active management by exception and 3. passive management by exception. Transactional leadership is most obvious in cases when the leader relies on passive management mechanisms, i.e. intervenes only when the work procedure has been violated or the set goal has not been achieved. He then threatens or punishes (Bass 1990). According to Burns (1978), transactional leadership is the most common style, but also a style that provides neither the manager nor the employee with a high level of motivation and intellectual stimulation.

Laissez faire (let it be) leadership style, as described by Lewin, Lippitt and White (1939) implies minimal involvement of the leader. Decisions are made by group members, taking responsibility for their outcomes. Avolio and Bass (2010) paid the least attention to this leadership style. In their instrument, they described it through only one leadership component - passive/avoidant leadership (this is also another name that Avolio and Bass use for this leadership style). If conscious, deliberate and planned activity is expected from the leader, in most cases, this leadership style is not desirable.

In practice, we almost never encounter pure leadership styles. Usually, a leader will show elements of two, or even three leadership styles, with one of them being the dominant one. This is why we commonly hear the phrase 'dominant leadership style'.

\section{TEACHER MOTIVATION}

In the mid-1980s, Ryan and Deci have moved away from attempts to explain human behaviour through a disturbed balance of needs and instrumental conditioning, setting the Self-determination theory. Overall human motivation, according to the Self-determination theory (Deci and Ryan, 1985), is the result of a complex interactive pro- 
cess between external and internal control. External control denotes extrinsic, and internal control denotes autonomous or intrinsic processes. The prevalence of intrinsic over extrinsic processes means achieving a higher level of self-determination, i.e. moving away from extrinsic to intrinsic motivation. The theory of self-determination thus shows motivation on a continuum that begins with amotivation, goes through different levels of extrinsic motivation (external regulation, introjected regulation, identified regulation) and finally ends with intrinsic motivation (internal regulation).

- Amotivation is defined by Ryan and Deci (2000) as the absence of any will to act in relation to the physical and/or social environment.

- External regulation is the least autonomous form of extrinsic motivation. It refers to motivation by means of punishment and rewards.

- Introjected regulation is internal but still (externally) controlled regulation of behaviour, in which a person resorts to a certain behaviour in order to avoid feelings of guilt or anxiety, or to achieve a sense of satisfaction and empowerment of the personality.

- Identified regulation implies a higher level of autonomy and greater freedom of choice compared to introjected regulation, because this behaviour is more in line with personal goals and identity.

- Intrinsic motivation is recognized in activities an individual performs for personal pleasure (one finds pleasure in performing the activity itself) without visible external benefit. Guay, Mageau and Vallerand (2003) point to three types of intrinsic motivation: motivation towards knowledge, motivation towards accomplishment and motivation towards stimulation.

The theory of self-determination is consistent with Herzberg's Two-Factor Theory of Motivation (Gagné and Deci 2005), which implies that the determinants of human behaviour in the workplace are hygiene factors and motivators. Motivators (Herzberg 1959), which are in the domain of intrinsic motivation, include success, responsibility, recognition, advancement, interest and personal development. Hygiene factors are, among others, interpersonal relationships, work conditions and personal life. They are primarily in the domain of external motivation. Only the satisfaction of motivators leads to job satisfaction and high motivation, while solely satisfying hygiene factors positions motivation on the neutral part of the motivational continuum (Herzberg 1959).

In researching teacher motivation, Dinham (2008) identified classroom conditions as motivators, which are mainly under the teacher's control, and which include his 
inner satisfaction in working with students and monitoring their progress and opportunities for professional development. Hygiene factors are broad context conditions, which are under the responsibility of education authorities and which can mostly have only a negative effect on teacher motivation. These include the social perception of the teaching profession, the policy of shaping and directing the education system, education reforms and work overload. As a third group, Dinham (2008) lists intermediate-level factors, which can be both motivators and hygiene factors. These include school management, decision-making, school climate, communication, teaching aids and school reputation in the local environment.

\section{SCHOOL CLIMATE}

The term school climate denotes the invisible dimension of school life, which is the result of the overall relationships of all its employees and students, and which each of them experiences subjectively, at the level of their own emotions, social relations and work environment. It is about the climate of the school as a group/organization.

According to Sušanj (2005), how we understand organizational climate is key for its precise definition. In that sense, from the earliest research, two directions were noted: objectivist or realistic and subjectivist or phenomenological. The first understanding implies that the climate exists objectively, as part of the reality of the organization. Even though it is composed of typical behaviours, attitudes and feelings, climate is an attribute that exists independently of the perception of the organization members. In contrast, according to the subjectivist understanding, climate refers to the perceptual and cognitive structuring of an organizational situation, common to its members. Such an attitude implies that the climate does not exist objectively and that it is the result of personal cognitive maps of all members of the organization, which they use to perceptually and cognitively structure organizational situations. Nevertheless, Sušanj (2005) finds two common features of the organizational climate in all of the above-mentioned definitions: perception (experience of the organizational environment) and descriptiveness (these are personal reports of members of the organization on how they experience the organizational environment).

In defining the school climate, Rafferty places emphasis on the role of principals and teachers in the creation of school climate, not mentioning students as having a particularly important role. 'School climate is the organizational climate in specific school conditions. It encompasses the totality of personalities - principals and teachers 
- in the interaction with the social and psychological environment of each school' (Rafferty 2003: 52).

Considering the above definitions, the school climate can be understood as a psychosocial climate, created in the school as a specific organization, and which consists of the behaviours, attitudes and feelings of its principal, teachers, expert associates and students.

This paper examines five dimensions of the school climate, defined by Johnson, Stevens and Zvoch (2007): 1. collaboration, 2. decision making, 3. instructional innovation, 4. student relations, 5. school resources.

\section{RESEARCH METHODOLOGY}

\section{Research subject}

The subject of the research is the relationship between the leadership style of the principal, as perceived by teachers, and the work motivation of teachers, through the perception of the school climate as a potential determinant of this relationship.

\section{Research aim}

The aim is to investigate the mediating role of the teacher school climate perception in relation to the principal leadership style, as perceived by teachers, and the work motivation of teachers in primary schools.

\section{Research hypothesis}

It is assumed that the leadership style of the school principal, as perceived by teachers, has a statistically significant correlation to the motivation of teachers to perform their work tasks, directly and indirectly, through shaping the teacher perceptions of the school climate.

\section{Respondents}

The sample, characterized as convenient, consisted of 467 primary and secondary school teachers from all 25 primary schools in the wider city area of Tuzla. According to the data collected in the schools, the total number of teachers employed at the time of the survey was 744, which corresponds to the number of printed and distributed sets of questionnaires. However, it should be emphasized that the actual number of teachers is less than 744 (it was impossible to obtain accurate information by looking at individual school databases), because, in order to accumulate work hours for their 
job to be considered full-time, some individuals were employed in more than one school. In such cases, teachers were advised to fill in the questionnaires in the school in which they have the largest number of working hours. The return of valid questionnaires was slightly less than $63 \%$. The gender distribution of respondents in the sample is asymmetric, which is a reflection of population imbalance: $307(65.7 \%)$ female teachers and $89(19.1 \%)$ male teachers, while $71(15.2 \%)$ respondents did not state their gender in the questionnaire. The age of the respondents ranged from 24 to 64 years $(\mathrm{M}=43.12 ; \mathrm{s}=9.15 ; \mathrm{Sk}=0.18 ; \mathrm{K}=-0.55)$. No statistically significant differences in age were found between the male and female subsamples, and neither were they found in length of service.

\section{Research methods and procedures}

The methodological framework of the empirical part of the paper is comprised of the survey method, which is represented through survey and scaling techniques. In addition to descriptive statistics procedures, multiple regression (OLS) and measures of general (RMSEA and SRMR) and comparative fit (CFI and TLI) were utilized. IBM SPSS software package was used for statistical data processing.

\section{Research instruments}

The Multifactor Leadership Questionnaire (MLQ), the Work Tasks Motivation Scale for Teachers (WTMST) and the School Level Environment Questionnaire (SLEQ) were used to collect data in the research.

The Multifactor Leadership Questionnaire (Avolio and Bass, 2010) consists of 36 statements arranged on eight subscales (idealized influence - attributed, idealized influence - behavior, inspirational motivation, intellectual stimulation, individualized consideration, contingent reward, management by exception and laissez-faire). Respondents completed their assessment of the frequency of forms of leader behavior expressed through statements on a five-point scale, where the answers range from 0 $=$ not at all, over $1=$ rarely, $2=$ sometimes, $3=$ often to $4=$ almost always.

The Work Tasks Motivation Scale for Teachers (Fernet, Senecal, Guay, March and Dowson 2008) consists of 90 statements, divided into six subscales, where each subscale corresponds to one group of teacher work tasks (class preparation, teaching, evaluation of students, classroom management, administrative tasks and complementary tasks). Each subscale lists three statements for each of the five types of motivation (intrinsic motivation, identified regulation, introjected regulation, external regulation and amotivation). Respondents express their agreement with the statements 
on a seven-point scale, where the answers range from $1=$ does not correspond at all, $2=$ correspond very little, $3=$ correspond a little, $4=$ correspond moderately, $5=$ correspond strongly, $6=$ correspond very strongly, up to $7=$ correspond completely.

The School Level Environment Questionnaire (Johnson, Stevens and Zvoch, 2007) consists of 21 statements, divided into five subscales, where each subscale corresponds to one dimension of the school climate: instructional innovation (4 items), collaboration (6 items), decision making (3 items), school resources (4 items) and student relations (4 items). All items are given in the form of five-point Likert scales (with modalities of $-2=$ completely disagree, $-1=$ disagree, $0=$ do not know, $1=$ agree to 2 = completely agree).

Another short questionnaire was used to collect basic information on the sociodemographic characteristics of the respondents - gender, age and work experience.

As a review of the relevant literature showed that in our country no serious study has yet been conducted on a sample of teachers using the Multifactor Leadership Questionnaire, the Work Tasks Motivation Scale for Teachers and the School Level Environment Questionnaire, an evaluation of these instruments was performed. After checking the factor validity through confirmatory factor analysis, and a detailed review of other relevant measurement properties, it was determined that the instruments used have satisfactory measurement properties. For the Multifactor Leadership Questionnaire and the Work Tasks Motivation Scale for Teachers, these properties can be evaluated on a qualitative scale in the range from good to exceptional. This especially refers to the internal measuring properties, while the factor validity of the constructs is in the range from acceptable to very good. Indicators of reliability, representativeness and homogeneity for the scales of leadership style, teacher motivation and school climate are shown in Table 1. 
Table 1. Indicators of reliability, representativeness and homogeneity for the Multifactor Leadership Questionnaire, the Work Tasks Motivation Scale for Teachers and the School Level Environment Questionnaire

\begin{tabular}{|c|c|c|c|c|c|c|c|}
\hline Subscales & $\alpha$ & $\beta$ & $\lambda 1$ & $\lambda 6$ & MSA & $\mathbf{H 2}$ & $\mathbf{N}$ \\
\hline Idealized influence (attributed) (IA) & .77 & .78 & .58 & .74 & .75 & .92 & 4 \\
\hline Idealized influence (behaviour) (IP) & .88 & .88 & .59 & .83 & .74 & .94 & 3 \\
\hline Inspirational motivation (IM) & .91 & .91 & .68 & .85 & .85 & .97 & 4 \\
\hline Intellectual stimulation (IS) & .85 & .85 & .64 & .82 & .79 & .95 & 4 \\
\hline Individualized consideration (IC) & .88 & .88 & .65 & .84 & .82 & .96 & 4 \\
\hline Contingent reward (CR) & .84 & .84 & .63 & .80 & .80 & .94 & 4 \\
\hline Active management by exception (AME) & .80 & .80 & .60 & .76 & .78 & .93 & 4 \\
\hline Laissez faire (LF) & .83 & .80 & .63 & .80 & .80 & .93 & 4 \\
\hline Intrinsic motivation & .92 & .92 & .87 & .95 & .89 & .60 & 18 \\
\hline Identified regulation & .92 & .92 & .87 & .94 & .89 & 67 & 18 \\
\hline Introjected regulation & .95 & .95 & .90 & .96 & .95 & .83 & 18 \\
\hline External regulation & .93 & .93 & .88 & .94 & .93 & .78 & 18 \\
\hline Amotivation & .94 & .94 & .88 & .95 & .94 & .79 & 18 \\
\hline Instructional innovation & .69 & .70 & .52 & .65 & .70 & .89 & 4 \\
\hline Collaboration & .74 & .75 & .62 & .74 & .72 & .76 & 6 \\
\hline Decision making & .30 & .41 & .22 & .30 & .64 & .83 & 3 \\
\hline Resources & .66 & .93 & .50 & .61 & .70 & .87 & 4 \\
\hline Student relations & .79 & .79 & .60 & .75 & .93 & .79 & 4 \\
\hline Full scale of school environment & .81 & .84 & .76 & .84 & .84 & .58 & 21 \\
\hline Scale of school environement, excluding items $4,9,14$ & .82 & .83 & .77 & .85 & .84 & .61 & 18 \\
\hline
\end{tabular}

Note. $\alpha$-Cronbach - reliability coefficient; $\beta$ - Lord - Kaiser - Caffrey reliability coefficient of the first principal component; $\lambda 1$ - Gutman - absolute lower limit of reliability, $\lambda 6$ - Gutman - absolute upper limit of reliability; MSA - normalized Kaiser - Meyer - Olkin representativeness coefficient; H2 - Momirović - relative size of the variance of the first principle image component; $\mathrm{N}$ - number of scale items.

The internal measuring characteristics of the School Level Environment Questionnaire are modest, which is largely determined by the small number of items in the subscales. Although the measured characteristics on three subscales of instructional innovation, resources and decision making are below the conventional level, we believe that it makes sense to keep the two subscales, while the third one should be discarded. This is because the analysis of internal measurement characteristics indicates that the decision making scale has no basis for its own existence, since the decision making factor and the associated items do not contribute to the reduction of the measurement error. It is assumed that the very nature of the items increased the variance of respondents' responses, in such a way that respondents showed significant differences in their perception of the given items, which further contaminated the measurement characteristics of the decision making scale.

As stated in the sample description, 744 sets of questionnaires were printed and distributed. The questionnaires were delivered to the schools in open envelopes in a 
number that corresponded to the number of engaged teachers, after which they were handed over to the teachers by expert associates, pedagogues-psychologists. After filling in the questionnaires, the teachers returned them to the pedagogues-psychologists in closed envelopes. The process took an average of five working days in each school.

\section{Research results}

Table 2 shows the descriptive statistics for the subscales of the Multifactor Leadership Questionnaire, the Work Tasks Motivation Scale for Teachers and the School Level Environment Questionnaire.

Table 2. Average values and standard deviations for the subscales of the Multifactor Leadership Questionnaire, the Work Tasks Motivation Scale for Teachers and the School Level Environment Questionnaire

\begin{tabular}{|c|c|c|c|c|}
\hline \multirow[b]{2}{*}{ Subscales } & \multicolumn{2}{|c|}{$\mathbf{M}$} & \multicolumn{2}{|c|}{$\boldsymbol{\sigma}$} \\
\hline & ss & psv & ss & psv \\
\hline Idealized influence (A) & 10.77 & 2.69 & 4.10 & 1.02 \\
\hline Idealized influence (B) & 9.01 & 2.73 & 3.07 & 0.81 \\
\hline Inspirational motivation & 11.99 & 2.99 & 3.97 & 0.99 \\
\hline Intellectual stimulation & 11.40 & 2.85 & 3.90 & 0.97 \\
\hline Individual consideration & 11.92 & 2.98 & 4.02 & 1.05 \\
\hline Contingetn reward & 11.31 & 2.82 & 4.01 & 1.00 \\
\hline Managm. by exception (A) & 11.38 & 2.84 & 3.64 & 0.91 \\
\hline Laissez faire style & 4.06 & 1.01 & 4.22 & 1.05 \\
\hline Intrinsic motivation & 85.02 & 4.72 & 20.58 & 1.14 \\
\hline Identified regulation & 100.92 & 5.60 & 17.92 & 0.99 \\
\hline Introjected regulation & 87.20 & 4.84 & 25.15 & 1.40 \\
\hline External regulation & 94.85 & 5.27 & 21.94 & 1.22 \\
\hline Amotivation & 45.13 & 2.50 & 22.60 & 1.25 \\
\hline
\end{tabular}

Note. $\boldsymbol{M}$ - arithmetic mean; $\boldsymbol{\sigma}$ - standard deviation; $\boldsymbol{s} \boldsymbol{s}$ - summative score created as a simple summation; $\boldsymbol{a} \boldsymbol{s} \boldsymbol{v}$ average scale value.

The obtained general efficiency of regression models for complete subscales of leadership (MLQ) and teacher perception of school climate (SLEQ)and leadership (MLQ) and teacher motivation (WTMST) is shown in Table 3. 
Table 3. General efficiency indicators of regression models: multiple correlation coefficient and determination coefficients for assessment models of teacher perce- tion of school climate, and models of teacher motivation

\begin{tabular}{lcccc}
\hline Model & $\boldsymbol{R}$ & $\boldsymbol{R}^{\mathbf{2}}$ & $\boldsymbol{\Delta R}^{\mathbf{2}}$ & Standard error \\
\hline Intrinsic motivation & 0.31 & 0.10 & 0.08 & 0.93 \\
Identified regulation & 0.35 & 0.13 & 0.11 & 0.92 \\
Introjected regulation & 0.22 & 0.05 & 0.03 & 0.97 \\
External regulation & 0.22 & 0.05 & 0.03 & 0.96 \\
Amotivation & 0.30 & 0.09 & 0.07 & 0.94 \\
Instructional innovation & 0.50 & 0.27 & 0.24 & 0.87 \\
Collaboration & 0.45 & 0.21 & 0.19 & 0.92 \\
Resources & 0.37 & 0.14 & 0.12 & 0.93 \\
Student relations & 0.18 & 0.03 & 0.02 & 0.98 \\
\hline
\end{tabular}

Note. $\boldsymbol{R}$ - multiple correlation coefficient; $\boldsymbol{R}^{2}-$ multiple determination coefficient; $\Delta \boldsymbol{R}^{2}-\operatorname{corrected} \boldsymbol{R}^{2}$

Table 4 shows the summative indicators of variance analysis for the tested regression models of the perceived leadership style and teacher motivation, and the perceived leadership style and school climate perception.

Table 4. Summative indicators of variance analysis for testing the regression model of the perceived leadership style and teacher motivation, and the perceived leadership style and school climate perception

\begin{tabular}{|c|c|c|c|c|c|c|}
\hline Model & & SS & df & MS & $\mathbf{F}$ & $\mathbf{p}$ \\
\hline & regression & 42.619 & 8 & 5.32 & 6.10 & 0.001 \\
\hline \multirow[t]{3}{*}{ Intrinsic motivation } & residual & 392.98 & 450 & 0.87 & & \\
\hline & total & 435.59 & 458 & & & \\
\hline & regression & 55.11 & 8 & 6.88 & 8.10 & 0.001 \\
\hline \multirow[t]{3}{*}{ Identified regulation } & residual & 382.31 & 450 & 0.85 & & \\
\hline & total & 437.41 & 458 & & & \\
\hline & regression & 21.46 & 8 & 2.68 & 2.87 & 0.005 \\
\hline \multirow[t]{3}{*}{ Introjected regulation } & residual & 420.00 & 450 & 0.93 & & \\
\hline & total & 441.46 & 458 & & & \\
\hline & regression & 20.55 & 8 & 2.57 & 2.76 & 0.01 \\
\hline \multirow[t]{3}{*}{ External regulation } & residual & 419.12 & 450 & 0.93 & & \\
\hline & total & 439.68 & 458 & & & \\
\hline & regression & 40.44 & 8 & 5.05 & 5.69 & 0.001 \\
\hline \multirow[t]{3}{*}{ Amotivation } & residual & 399.54 & 450 & 0.89 & & \\
\hline & total & 439.98 & 458 & & & \\
\hline & regression & 117.34 & 8 & 14.66 & 19.26 & 0.001 \\
\hline \multirow[t]{3}{*}{ Instructional innovation } & residual & 348.65 & 458 & 0.76 & & \\
\hline & total & 466.00 & 466 & & & \\
\hline & regression & 96.69 & 8 & 12.08 & 14.98 & 0.001 \\
\hline \multirow[t]{3}{*}{ Collaboration } & residual & 369.30 & 458 & 0.81 & & \\
\hline & total & 466.000 & 466 & & & \\
\hline & regression & 63.82 & 8 & 7.97 & 9.08 & 0.001 \\
\hline \multirow[t]{3}{*}{ Resources } & residual & 402.17 & 458 & 0.87 & & \\
\hline & total & 466.000 & 466 & & & \\
\hline & regression & 16.22 & 8 & 2.02 & 2.06 & 0.03 \\
\hline \multirow[t]{2}{*}{ Student relations } & residual & 449.77 & 458 & 0.982 & & \\
\hline & total & 466.00 & 466 & & & \\
\hline
\end{tabular}

Note. $\boldsymbol{S S}$ - sum of squares; $\boldsymbol{d} \boldsymbol{f}$ - degrees of freedom; $\boldsymbol{M S}$ - mean squares; $\boldsymbol{F}$ - Fisher F ratio 
Regression models show that there is a connection between the perceived leadership style of school principals and the work motivation of teachers, as well as between the perceived leadership style and experience of the school climate. A maximum of $13 \%$ of motivation variance and $24 \%$ of the school climate perception variance can be explained directly by the leadership style of the school principal. The values of predictor variables suggest that transformational leadership, through the idealized influence variable, positively contributes to instructional innovations and teacher collaboration, while they are negatively affected by laissez faire leadership. When it comes to teacher motivation, predictor variables suggest that transformational leadership mainly contributes to intrinsic motivation, transactional aspects of external motivation - introjected, identified and external regulation and laissez faire amotivation.

In order to address the main question of this research, i.e. its hypothesis, the structural model was tested, which assumed that the exogenous variable leadership has a direct impact on the constructs of school climate and teacher motivation, but also an indirect impact on motivation, through climate. The leadership construct is presented through eight sets of items (parcels), which are compiled according to the criterion of the size of absolute correlations of items in relation to the corresponding highlighted first main component of the leadership questionnaire. The construct of climate is presented through four sets of indicators, and teacher motivation through five sets of indicators, also compiled according to the criterion of the size of absolute correlations of items in relation to the corresponding principal component of the scale. A covariance relationship is assumed between the constructs of climate and teacher motivation, and the variances of the constructs of climate and teacher motivation are limited to value 1 . The initial assumed model is shown by the path diagram in Figure 1. 


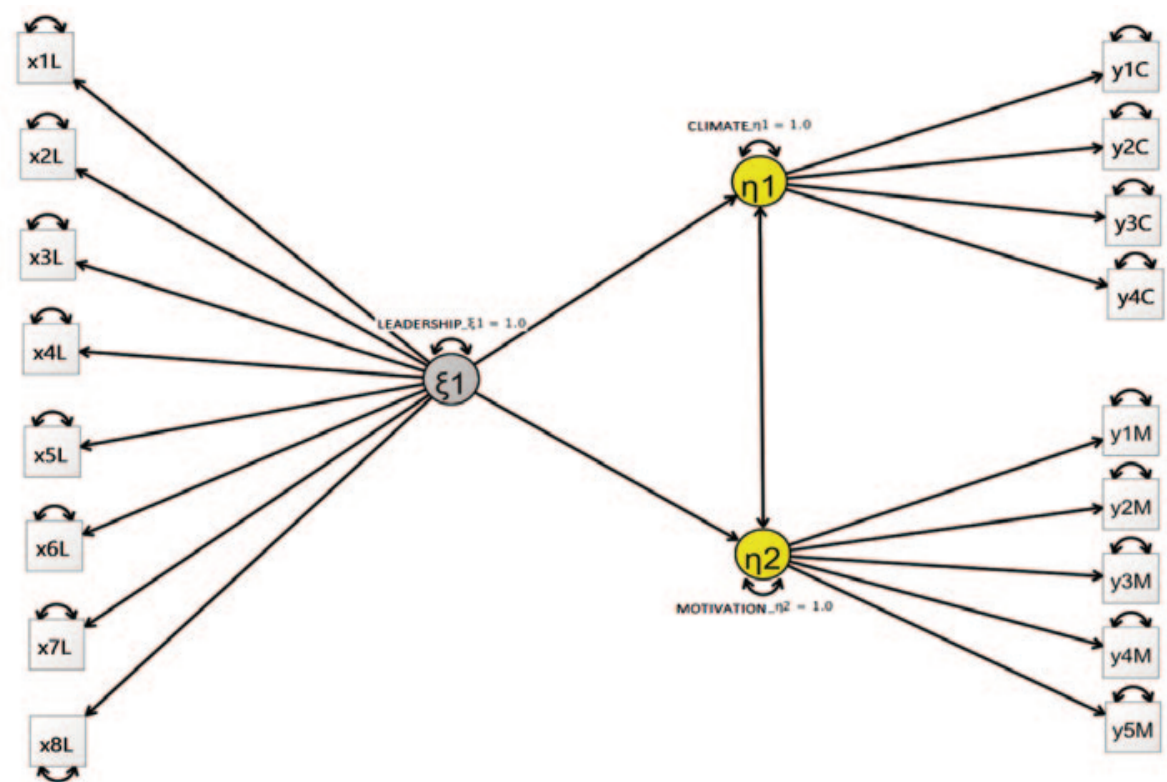

Figure 1. Assumed relations between leadership, school climate and teacher motivation. $\mathrm{x} 1 \mathrm{~L}, \mathrm{x} 2 \mathrm{~L}, \ldots \mathrm{x} 8 \mathrm{~L}$ denote sets of items of the Multifactor Leadership Questionnaire (MLQ) Questionnaire; y1C, y2C, ... y4C denote sets of the Work Tasks Motivation Scale for Teachers (WTMST) items, and y1M, y2M, ... y4M denote sets of items of the School Level Environment Questionnaire (SLEQ). All sets of items are compiled according to the criterion of the size of absolute correlations of items in relation to the corresponding highlighted first main component.

The value of the Mardia test of multivariate normality (relative multivariate kurtosis) amounts to $\mathrm{RMK}=1.152$, and is statistically significant $(\mathrm{p}<0.01)$, which means that the data deviate from the model of multivariate normality to some extent. Accordingly, model verification was performed on an asymptotic covariance matrix, while estimation was conducted by using the robust maximum likelihood method, which is resistant to deviations from the normal distribution model. A schematic representation of the standardized solution for the assumed model is shown in Figure 2. 


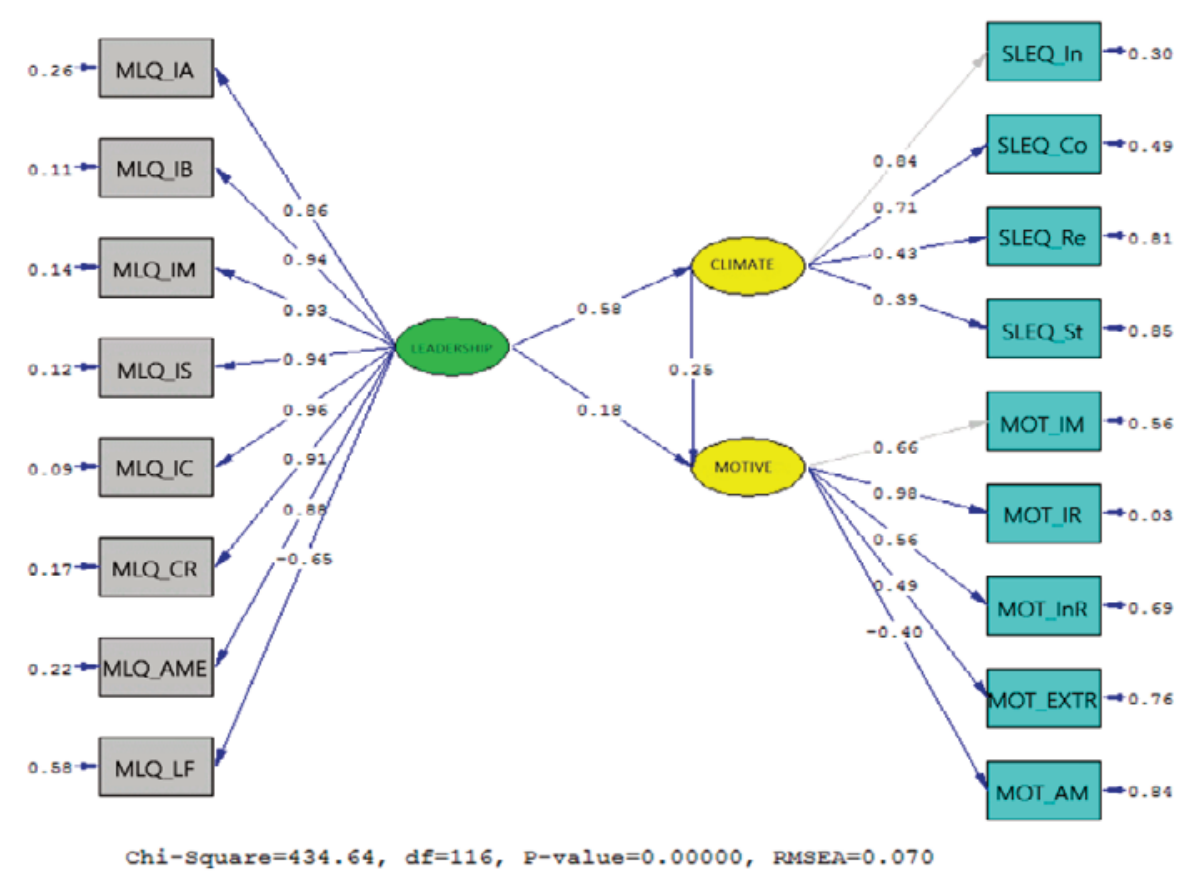

Figure 2. Final structural model with significant coefficients presented in a standardized form. MLQ_IA - Idealized influence (Attribution); MLQ_IB - Idealized influence (behaviour); MLQ_IM - Inspirational motivation; MLQ_IS - Intellectual stimulation; MLQ_IC - Individualized consideration; MLQ_CR Contingent reward; MLQ_AME - Active management by exception; MLQ_LF - Laissez faire; SLEQ_In - Instructional innovation; SLEQ_Co - Collaboration; SLEQ_Re - Resources; SLEQ_St - Student Relations; MOT_IM - Intrinsic motivation; MOT_IR - Identified regulation; MOT_InR - Introjected regulation; MOT_EXTR - Extrinsicregulation; MOT_AM - Amotivation.

Standardized saturations represent simple correlations between indicators and related factors, so the amount of covered variance of manifest variables representing the leadership factor (MLQ) ranges from $42 \%$ to $91 \%$. The climate factor (SLEQ) is also adequately represented by indicators covering $15 \%$ to $70 \%$ of variance, and the same is the case with the teacher motivation construct (WTMST), where the range of variance spanned between $16 \%$ and $97 \%$. About one third of the climate variance $\left(\mathrm{R}^{2}=0.33\right)$ is under the direct influence of leadership, while about $15 \%$ of the moti- 
vation variance can be explained through the influence of leadership and climate (MOTIVATION $=0.25 *$ CLIMATE $+0.18 *$ LEADERSHIP, $\mathrm{R}^{2}=0.15$ ).

Following the conventional criteria in the evaluation of the general fit index, the obtained data are in reasonable agreement with the assumed structural model on the relations between leadership, school climate and teacher motivation. $\left(\chi^{2} \mathrm{SB}(116)=434.64, \mathrm{p}<0.001 ; \mathrm{SRMR}=0.054 ; \mathrm{RMSEA}=0.070,90 \% \mathrm{IP}(0.062-0.078)\right.$; $\mathrm{CFI}=0.98 ; \mathrm{TLI}=0.98)$. The only exception to this statement is the value of the SatorraBentler-og $\chi 2$ statistics, which indicates poor agreement. However, $\chi 2$ as a measure of general agreement has been labeled by a significant number of authors as a very weak general measure of model estimation (Brown, 2015; Diamantopoulos and Siguaw, 2000; Kline, 2010). Therefore, preference in interpretation is given to other measures of general and comparative fit. The Root Mean Square Error of Approximation (RMSEA) and the Standardized Root Mean Squared Residual (SRMR) as measures of the absolute agreement of the model with the observed data indicate a moderate agreement of the data with the model, while the Comparative Fit Index (CFI) and Tucker-Lewis Index (TLI) as relative indicators of fit show a very good agreement of the model with the data.

\section{DISCUSSION}

Considering the above, it can be concluded that the leadership style of the school principal, as perceived by teachers, affects teacher motivation directly, and indirectly, through the teacher's perception of the school climate. In other words, school principals, through their leadership actions (as seen by teachers) influence the creation of the school climate (teacher experience), which is indirectly reflected in teacher motivation. Nevertheless, the small amount of explained variance is an indicator that teacher motivation in its totality is mostly determined by the sum of the effects of other factors.

The available literature and earlier research contain far less ground for the assumption of a parallel indirect influence (through climate) of the perceived leadership style of the school principal on teacher motivation, compared to the direct relationship of these two variables. Most studies have investigated the relationship between leadership style and school climate (Allen, Grigsby, \& Peters 2015; DuPont 2009; Gumus, Bulut, \& Bellibas 2013; Silva, Amante, \& Morgado 2017), leadership style and motivation (Alasad 2017; Eres 2011; Eyal and Roth 2011) and school climate and mo- 
tivation (Ladyong 2014; Raman, Ling, \& Khalid 2015), however, none of these considered all variables at the same time.

As the first principal components of all instruments were used to test the model of indirect influence, the obtained variance is somewhat higher in the case of school climate perception as well as the case of teacher motivation in relation to the perceived leadership style. Still, the ratio is maintained and in the final model the role of the principal is more important in creating the school climate than the motivation of teachers as well. Such a result shows that motivation is less dependent on the principal than the school climate. The reason for this might lie in the fact that motivation is a more complex construct, which is influenced by a number of variables, including those that belong to the group of motivators. These strictly concern the individual (intrinsic motivation, which is conditioned by the right choice of occupation, teacher's ability to feel satisfaction with their job, the possibility of professional training), and hygiene factors that are, in the environment where the research was conducted, mostly outside the scope of the principal's influence, and even the school itself, such as the value of the teaching profession, employment status of teachers, job security, income. Dissatisfaction with hygiene factors, according to Herzgberg (1959), prevents the motivators from their influence, which results in a situation where the principal's leadership role will have minimal opportunity to come to the fore. The employment status and job security of teachers are illustrated by the following data: at the time of collecting data for this research, 744 teachers were working in 25 schools in the wider city area of Tuzla (data obtained in each school individually). The competition for employment of teachers and expert associates in primary and secondary schools in Tuzla Canton (Dnevni Avaz 2015), announced, for that school year, 194 teacher positions for temporary work in these 25 schools. These positions mostly entailed parttime jobs, which sometimes included only one or two school hours per week (which represents $5-10 \%$ of the full-time work norm). In other words, at the time of data collection in the schools that participated in the research sample, between one-fifth and one-quarter of teachers worked part-time, less than the full-time work norm, which could greatly affect their motivation. Additionally, in efforts to accumulate work hours for their job to be considered full-time, some teachers were engaged in two or more schools at the same time, while others could not achieve working full-time at all. In future research, these circumstances could very likely explain a part of the variance in teacher motivation.

On the other hand, as this research shows, the principal has a much greater influence on the perception of the school climate among teachers. Although the school 
differs from other types of work organizations in its function and organization, within the framework set externally - through clear rights and obligations that the school has in relation to its founder, the fact that it is a non-profit organization, that the requirements for appointing a school principal are pre-set, that the principal's abilities are limited when it comes to selection and hiring of teachers, that the school does not control its funds independently, and that, above all, performs a very specific social role of education (Law on Primary Education of Tuzla Canton, Official Gazette TK 9/15), each school forms a somewhat specific value system, with specific relationships and their dynamics. This creates a specific school climate, which can significantly affect the innovation in the work of teachers, mutual collaboration, and even the perception of available school resources. Therefore, the role of the principle in the school climate is more obvious than his motivational role.

The connection between the perceived leadership style and teacher motivation, through the experience of school climate, can be explained by cohesion forces, to which the principal contributes by emphasizing the mission and vision of the school and group efforts to achieve goals. This results in better teacher-principal relations, but also stronger cooperation between teachers themselves. In such an environment, the school becomes a place where the need for professional development and advancement is more easily met, where younger teachers can rely on their more experienced colleagues, which also creates a sense of security through the provided support, and, to some extent, develops healthy competition. Given that all of the above are intrinsic motives, the explanation makes more sense, as the principal's ability for external reinforcement is limited. As there are no significant levels of motivation when hygiene factors are not met, the principal's role in creating motivation is theoretically less important. Results obtained by Sargent and Hannum (2005) support this observation, identifying three groups of factors that affect teachers' job satisfaction: community factors (economic power of the community, community involvement and support), school environment factors (timely salary, level of allocation of funds per student, organizational structure of the school) and individual teacher characteristics (gender, age, work experience, level of education, personal expectations). The most significant contribution to teachers' job satisfaction was given by personal factors (older teachers, teachers with a lower level of education and women were more satisfied with their job).

Ladyong (2014) also found a connection between the perception of the organizational climate of the school and the teacher motivation, through collegial leadership and the relationship of the school with the wider community, as predictor variables. 
She observed the organizational climate of the school through four dimensions: collegial leadership, teacher professionalism, school relations with the wider community and academic pressure. On the other hand, the dimensions of teacher motivation were achievement, professional advancement, job satisfaction, recognition, and responsibility. She explained $35 \%$ of the variance in teacher motivation for performing work tasks by the teachers' perception of the climate. Therefore, Ladyong did not separate collegial leadership and organizational climate, which means that she attributed a much greater importance to climate than this paper does. Nevertheless, this broader meaning encompasses the initial independent variable in this research - the principal's leadership style, which makes the results obtained in both papers consistent.

\section{CONCLUSION}

The hypothesis set at the beginning of the research was confirmed. It can be concluded that the leadership style of the school principal, as perceived by teachers, affects teacher motivation directly, and indirectly, through the teachers' perception of the school climate. In other words, school principals, through their leadership actions (as seen by teachers), influence the creation of the school climate (teacher experience), which indirectly impacts teacher motivation. Nevertheless, a small amount of explained variance is an indicator that teacher motivation in its totality is mostly determined by the sum of the effects of other factors.

The advantage of this research paper is reflected in the lack of empirical papers that would simultaneously question the relationship between the leadership style of school principals, the school climate and the motivation of teachers. Limitation of the research paper is reflected in the specific sample of respondents, determined by the characteristics of the school system. Future research could, therefore, be conducted on a different sample of teachers. 


\section{REFERENCES}

1. Alasad, Salih (2017), "The leadership styles of principals in bedouin secondary School and teachers motivation", Philosophy Study, Vol. 7, No. 3, 153-168.

2. Allen, Nancy, Bettye Grigsby, Michelle L. Peters (2015), "Does leadership matter? Examining the relationship among transformational leadership, school climate, and student achievement", International Journal of Educational Leadership Preparation, Vol. 10, No. 2, 1-22.

3. Avolio, Bruce J., Bernard M. Bass (2002), Developing potential across a full range of leadership: Cases on transactional and transformational leadership, Lawrence Erlbaum associates, New Jersy

4. Avolio, Bruce J., Bernard M. Bass (2010), Višefaktorski upitnik rukovođenja $(M L Q)$ : priručnik. Naklada Slap, Jastrebarsko

5. Bass, Bernard M. (1985), Leadership and performance beyond expectations, Free Press, New York

6. Bass, Bernard M. (1990), "From transactional to transformational leadership: Learning to share the vision", Organization dynamics, 18(3), 19-36.

7. Bass, Bernard M., Ronald E. Riggio (2006), Transformational leadership. Second edition, Lawrence erlbaum associates, New Jersy

8. Burns, James MacGregor (1978), Leadership, Open road integrated media, New York

9. Deci, Edward L., Richard M. Ryan (1985), Intrinsic motivation and self-determination in human behavior, Springer science+business media, New York

10. Deci, Edward L., Richard M. Ryan (2000), "The „what“ and „why“ of goal pursuits: Human needs and the self-determination of behavior", Psychological inquiry, Vol. 11, No. 4, 227-268.

11. Diamantopoulos, Adamantios, Judy A. Siguaw (2000), Introducing LISREL, Sage Publications, London

12. Dinham, Stephen (2008), How to get your school moving and improving, Acer press, Camberwell

13. Dnevni avaz - Oglasi (2015), Konkurs za prijem u radni odnos nastavnika i stučnih saradnika u osnovnim i srednjim školama Tuzlanskog kantona, avaz roto press, 1 . august, 1-10.

14. DuPont, Jonathan P. (2009), Teacher perceptions of the influence of principal instructional leadership on school culture: A case study of the American embassy school in New Dwlhi, India, PhD Thesis, University of Minnesota 
15. Eres, Figen (2011), "Relationship between teacher motivation and transformational leadership characteristics of school principals", International journal od education, Vol. 3, No. 2, 1-17.

16. Eyal, Ori, Guy Roth (2011), "Principals' leadersship and teacher's motivation: Self-determination theroy analysis", Journal of educational administration, Vol. 42, No. 3, 256-275.

17. Fernet, Claude, Caroline Senécal, Frédéric Guay, Herbert Marsh, Martin Dowson (2008), "The work task motivation scale for teachers (WTMST)", Journal of career assessment, Vol. 16 No. 2, 256-279.

18. Gagné, Marylène, Edward L. Deci (2005), "Self-determination theory and work motivation", Journal of organizational behavior, 26(4), 331-362.

19. Giblar, Charlotte Rognmoe (2014), Principals' Leadership and Teachers' Motivation: A Study of the Relationship in the School Reform Era, PhD Thesis, Lynchburg College

20. Gorozidis, Gerogios, Athanasios G. Papaioannou (2014), "Teachers' motivation to participate in training and to implement innovations", Teaching and teacher education, No. 39, 1-11.

21. Guay, Frédéric, Geneviève A. Mageau, Robert J. Vallerand (2003), "On the hierarchial structure of self - determined motivation: A test of top-down, bottom-up, reciprocal, and horizontal effects", Personal and social psychology bulettin, Vol. 29, No. 8, 992-1004.

22. Gümüş, Sedat, Okan Bulut, Mehmet Şükrü Bellibaş (2013), "The relationship between principal leadership and teacher collaboration in Turkish primary schools: A multilevel analysis", Education research and perspectives: An international journal, Vol. 40, 1-29.

23. Herzberg, Frederic, Bernard Mausner, Barbara B. Snyderman (1959), The Motivation to Work, John Wiley \& Sons, New York

24. De Jesus, Saul Neves, Villy Lens (2005), "An integrated model for the study of teacher motivation", Applied psychology: An international review, 54(1), 119-134.

25. Johnson, Bruce, Joseph J. Stevens, Keith Zvoch (2007), "Teachers' perceptions of school climate: A validity study of scores from the revised school environment questionnaire", Educational and psychological measurement, Vol. 67, No 5, 833-844.

26. Karabenick, Stuart, AnneMarie Conley (2011), Teacher motivation for professional development, National science foundation, Michigan 
27. Krech, David, Richard S. Crutchfield (1969), Elementi psihologije, Naučna knjiga, Beograd

28. Ladyong, Brenda L. (2014), "Organizational climate and teachers' work motivation: A case study of selected schools in Prachinburi, Thailand", Scholarly journal of education, Vol. 3(5), 52-57.

29. Lewin, Kurt, Ronald Lippitt, Ralph K. White (1939), "Patterns of aggressive behavior in experimentally created „social climates“", Journal of social psychology, 10, 271-301.

30. Perlman, Dana J. (2013), "Effective teaching and motivation: Application of self - determination theory", Journal of research, policy and practice of teach ers i teacher education, Vol. 3, No. 2, 31-37.

31. Rafferty, Timothy J. (2003), "School climate and teacher attitudes toward upward communication in secondary scholls", American secondary education, 31(2), 49-70.

32. Raman, Arumugam, Chang Chi Ling, Rozalina Khalid (2015), "Relationship between school climate and teachers' commitment in an excellent school Kubang Pasu district, Kedah, Malaysia", Mediterranean journal of social sciences, Vol. 6, No. 3, 163-173.

33. Ryan, Richard M., Edward L. Deci (2000), "Intrinsic and Extrinsic Motivations: Classic Definitions and New Directions", Contemporary Educational Psychology, 25, 54-77.

34. Sargent, Tanja, Emily Hannum (2005), "Keeping teachers happy: Job satisfaction among primary school teachers in rural Northwest China", Comparative education review, Vol. 49, Iss. 2, 173-204.

35. Shepherd-Jones, Anna R., Jill D Salisbury-Glennon (2018), "Perceptions matter: The correlation between teacher motivation and principal leadership style", Journal of Research in Education, Vol. 28, No. 2, 93-131.

36. Silva, José C., Lúcia Amante, José Morgado, J. (2017), "School climate, principal support and collaboration among Portugese teachers", European journal of teacher education, 40(4), 1-17.

37. Službene novine Tuzlanskog kantona (2015), Zakon o osnovnom odgoju i obrazovanju, SkupštinaTuzlanskog kantona, br. 9, 1154-1176.

38. Sušanj, Zoran (2005), Organizacijska klima i kultura, Naklada Slap, Jastrebarsko

39. Wasserman, Egoza, Sigal Ben-eli, Ortal Yehoshua, Ravit Gal (2016), "Relationship between the Principal's Leadership Style and Teacher Motivation", International Journal of Learning, Teaching and Educational Research, Vol. 15, No. 10, 180-192. 


\section{DOŽIVLJAJ ŠKOLSKE KLIME KAO POSREDUJUĆI FAKTOR U ODNOSU MOTIVACIJE NASTAVNIKA I OPAŽENOG STILA RUKOVOĐENJA ŠKOLSKIH DIREKTORA}

\section{Sažetak:}

U radu su predstavljeni rezultati istraživanja provedenog na 467 nastavnika iz 25 osnovnih škola na širem gradskom području Tuzle. Predmet istraživanja bio je odnos rukovoditeljskog stila direktora, kako ga percipiraju nastavnici, i radne motivacije nastavnika, uz posredstvo doživljaja školske klime kao potencijalne determinante ovog odnosa. Za prikupljanje podataka korišteni su Višefaktorski upitnik rukovođenja (MLQ), Skala nastavničke motivacije (WTMST) i Skala školske klime (SLEQ). Dobijeni rezultati ukazuju da stil rukovođenja školskog direktora, kako ga opažaju nastavnici, utječe na nastavničku motivaciju direktno, te indirektno, putem nastavničkog doživljaja školske klime. Na ovaj način je, međutim, objašnjen mali dio ukupne varijance motivacije, što sugerira da je motivacija većinski određena sumom djelovanja drugih faktora.

Ključne riječi: motivacija nastavnika; školska klima; školski direktor; transformacijsko, transakcijsko, laissezfaire rukovođenje; teorija samoodređenja

Adresa autora

Authors' address

Gabriel Pinkas

University of Tuzla

Faculty of Humanities and Social Sciences

gabriel.pinkas@unitz.ba 
